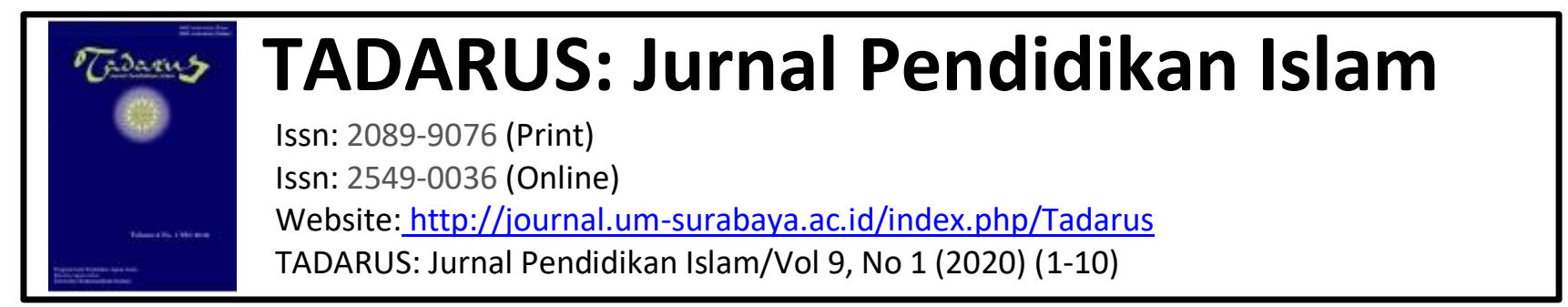

\title{
IMPLEMENTASI MODEL PEMBELAJARAN EDUTAINMENT DALAM PENGEMBANGAN KREATIVITAS BELAJAR SISWA MATA PELAJARAN PAI DI SMPN 35 SURABAYA
}

\author{
${ }^{1}$ Shokhibul Arifin, \\ ${ }^{1}$ shokhibul@fai.um-surabaya.ac.id \\ Program Studi Pendidikan Agama Islam, Universitas Muhammadiah Surabaya
}

\begin{abstract}
Abstrak
Penelitian model pembelajaran Edutainment Dalam Pengembangan Kreativitas Belajar Siswa Mata Pelajaran PAI di Kelas VIII SMPN 35 Surabaya. Dalam penelitian ini, peneliti menggunakan penelitian kualitatif deskriptif. Sebab penelitian ini menitik beratkan pada proses aplikasi "Pelaksanaan pembelajaran edutainment dalam pengembangan kreativitas mata pelajaran PAI", maka metode penelitian yang sesuai dan tepat adalah menggunakan metode penelitian kualitatif. Hasil Implementasi Model Pembelajaran Edutainment dalam pengembangan kreativitas belajar siswa pada bidang studi PAI di SMP Negeri 35 Surabaya dilakukan dengan menggunakan metode pembelajaran berbeda-beda dan bervariasi yang digunakan secara bergantian, diciptakannya dalam kondisi kelas yang ceria, menyenangkan dan penuh kegembiraan
\end{abstract}

Kata kunci: Pembelajaran Edutainment, Pengembangan Kreativitas Belajar

\section{Pendahuluan}

Dalam era tersebut kita dituntut mampu berperan dalam persaingan bebas, lebih-lebih dalam dunia pendidikan. Konsekuensi logisnya, sumber daya manusia (SDM) yang unggul dan memadai menduduki posisi yang sangat vital dan strategis dalam konteks saat ini. Pendidikan merupakan salah satu kebutuhan yang mendapat prioritas utama dalam kehidupan manusia. Sebab, pendidikan menjadi suatu jalan atau cara yang mengantarkan manusia untuk mencapai tujuan hidupnya. Bahkan pendidikan menjadi suatu kewajiban yang harus dijalani manusia dalam kehidupannya. Sebagaimana dijelaskan dalam hadits Nabi Muhammad SAW: ${ }^{1}$

$$
\text { عن انس ابن مالك, قال رسول الله ص.م. طلب العلم فريضة على كل مسلم و المسلمة }
$$

Artinya: "Dari Anas Ibnu Malik berkata, Sabda Rosulullah SAW: "Mencari ilmu merupakan kewajiban bagi setiap orang muslim (laki-laki dan perempuan)"

\footnotetext{
${ }^{1}$ Sunan Ibnu Majjah. Juz 1 Hadits No. 224, (Bairut: Dar al-Kitab al-Ilmiah, tt), 81.
} 
Pendidikan mempunyai peran yang amat menentukan bagi perkembangan dan perwujudan diri individu, terutama bagi perkembangan bangsa dan negara. Kemajuan suatu kebudayaan tergantung kepada cara kebudayaan tersebut mengenali, menghargai dan memanfaatkan sumber daya manusia (SDM). Hal ini berkaitan erat dengan kualitas pendidikan yang diberikan kepada anggota masyarakatnya, salah satunya kepada peserta didik. ${ }^{2}$

Adapun pendidikan di sini tidak hanya sebagai transfer of knowledge, lebih dari itu ada tujuan pembentukan kepribadian. Pendidikan juga merupakan usaha sadar yang dilakukan oleh pendidik terhadap perkembangan jasmani dan rohani peserta didik menuju terbentuknya kepribadian utama. ${ }^{3}$ Sehingga siswa dapat mengenal potensi yang dimilikinya dan kemudian dapat mengembangkan potensinya sesuai bakat dan moral. Dalam hal ini betapa pentingya kedudukan pendidikan Agama dalam pembangunan manusia Indonesia seutuhnya. Buktinya, dengan ditempatkannya unsur agama dalam sendi-sendi kehidupan berbangsa dan bernegara. Sila pertama dalam Pancasila adalah sila ketuhanan YME, yang memberikan makna bahwa bangsa kita adalah bangsa yang beragama. Untuk membina bangsa yang beragama, pendidikan agama ditempatkan pada posisi strategis dan tidak dapat dipisahkan dalam sistem pendidikan nasional kita. Keterkaitan antara pendidikan agama dengan sistem pendidikan nasional disebutkan dalam tujuan pendidikan nasional yaitu bahwa "Pendidikan nasional bertujuan untuk meningkatkan kualitas manusia Indonesia, yaitu manusia yang beriman dan bertaqwa terhadap Tuhan YME, berbudi luhur, berkepribadian, mandiri, maju, teguh, cerdas, kreatif, terampil, berdisiplin, beretos kerja, profesional, demokratis, berilmu, cakap, sehat jasmani dan rohani serta tanggung jawab."

Pendidikan agama dalam sistem pendidikan nasional memiliki posisi yang kokoh, yang secara yuridis merupakan bagian yang tidak terpisahkan dengan pembangunan manusia Indonesia seutuhnya. Dalam UU Sisdiknas 2003 Bab I Pasal I dinyatakan bahwa pendidikan Agama adalah bagian dari proses pendidikan nasional. Pendidikan adalah usaha sadar dan terencana untuk mewujudkan suasana belajar dan proses pembelajaran agar peserta didik secara aktif mengembangkan potensi dirinya

\footnotetext{
${ }^{2}$ Utami Munandar, Kreativitas dan Keberbakatan: Strategi Mewujudkan Potensi Kreatif dan Anak Berbakat, (Jakarta: PT. Gramedia, Pustaka Utama, 2002), 4.

${ }^{3}$ Ahmad D. Marimbah, Pengantar Filsafat Pendidikan Islam, (Bandung: Al-Maarif, 1974), 19.

${ }^{4}$ UU Sisdiknas Pasal 40 Ayat 2. Sisdiknas, (Surabaya; Media Center, 2005), 8.
} 
untuk memiliki kekuatan spiritual keagamaan, pengendalian diri, kepribadian, kecerdasan, akhlak mulia, serta ketrampilan yang diperlukan dirinya, masyarakat, bangsa dan negara.

Dengan demikian, bangsa Indonesia menempatkan pendidikan agama pada kedudukan yang tinggi dalam sistem pendidikan nasional dan menjadi bagian yang tak terpisahkan dengan perkembangan bangsa Indonesia. Pendidikan agama di sini mendapat prioritas utama. Namun, terdapat pertentangan dengan praktik Pendidikan Agama Islam saat ini, karena pendidikan agama tidak mampu memberdayakan peserta didik dalam penguasaan pengetahuan teoritis, penghayatan norma, dan aplikasinya dalam kehidupan sehari-hari, bahkan lebih jauh lagi tercerabutnya agama dari kehidupan nyata baik di bidang politik, ekonomi, ilmu pengetahuan, sosial dan kebudayaan. Kenyataan ini tergambar dalam realitas sosial yang dihadapi bangsa Indonesia dengan munculnya krisis multi dimensi, terutama krisis moral bangsa. ${ }^{5}$ Oleh karena itu, pendidikan agama bisa menjadi salah satu solusi di tengah keadaan bangsa saat ini agar tidak terperosot ke jurang keruntuhan dan krisis moral yang semakin mendalam.

Proses pembelajaran yang digunakan para guru agama Islam selama ini lebih banyak menggunakan metode ceramah. Guru memberi penjelasan dengan berceramah mengenai materi pelajaran dan siswa sebagai pendengar. Metode pembelajaran semacam ini kurang memberikan arahan pada proses pencarian, pemahaman, penemuan dan penerapan serta menjadikan siswa menjadi jenu, bosan dan malas belajar. Akibatnya pendidikan agama Islam kurang dapat memberi pengaruh yang berarti pada kehidupan siswa sehari-hari, bahkan mengakibatkan terjadinya krisis multi dimensi terutama krisis moral pada kalangan siswa. ${ }^{6}$

Di sisi lain, model pembelajaran yang diimplemantasikan sekolah-sekolah saat ini pada umumnya masih bersifat konvensional, yang belum mampu menjadikan semua siswa di kelas bisa menguasai tujuan-tujuan umum pembelajaran terutama bagi siswa yang berkemampuan rendah. ${ }^{7}$

Untuk menghadapi tantangan ini pendidikan harus mampu mencari model penyampaian pendidikan agama yang baru, yang bisa memotivasi peserta didik untuk

\footnotetext{
${ }^{5}$ Hanun Asrohah, Pendidikan Islam dalam KBK: Studi tentang Pengembangan Pembelajaran PAI Model di MIN Malang, (Surabaya: Nizamia, 2004), 147.

${ }^{6}$ Sutrisno, Rovolusi Pendidikan di Indonesia: Membedah Metode dan Teknik Pendidikan Berbasis Kompetensi, (Yogyakarta: Ar-Ruzz, 2005), 42.

7 Syafrudin Nurdin, Model Pembelajaran yang Memperhatikan Keberagaman Individu Siswa dalam KBK, ( Jakarta: PT. Quantum Teaching, 2005), 4.
} 
secara aktif menjawab persoalan-persoalan kehidupan sehari-hari. Oleh karena itu model pengajaran yang bersifat indoktrinasi-dogmatis dan normatif, sudah tidak cocok lagi untuk digunakan, pendidikan agama harus disampaikan secara empirikproblematis, sehingga secara aktif peserta didik mampu mengintegrasikan ajaranajaran agama dengan problem-problem sosial yang dihadapinya. Hal ini penting dalam pembentukan sikap sosial anak, dimana anak dilatih untuk menggunakan persepsi agamis terhadap realitas kehidupan.

Di sini guru agama harus selalu berusaha mengajak peserta didik untuk melakukan refleksi teologis dalam menghadapi setiap bentuk tantangan hidup. Dengan demikian kehidupan peserta didik sehari-hari tidak sampai terjadi hampa Iman dan Taqwa, sehingga dalam melakukan setiap kegiatan tidak lagi takut pada guru/orang lain, akan tetapi karena terpanggil oleh iman dan taqwanya terhadap Tuhan YME. Di samping pendidikan agama disampaikan secara empirik-problematis, juga disampaikan dengan pola hemeostatika yaitu keselarasan antara akal kecerdasan dan perasaan yang melahirkan perilaku akhlakul karimah dalam kehidupan berbangsa dan bernegara. Pola ini menuntut upaya lebih menekankan pada faktor kemampuan berfikir dan berperasaan moralis yang merentang ke arah Tuhan, dan ke arah masyarakatnya, di mana iman dan Taqwa menjadi rujukannya. ${ }^{8}$

Dewasa ini, pendidikan agama dianggap telah menciptakan penyeragaman bagi anak. Dengan demikian pendidikan cenderung telah menjadi proses pemaksaan yang berlangsung lama dan kurang sistematis, sehingga kurang mampu mengembangkan ekspresi dan kreasi anak. Sistem pendidikan kita juga cenderung berorientasi pada hasil pendidikan yang harus dicapai secara instant sehingga kurang mementingkan proses belajar secara seimbang. Kenyataan ini dapat kita lihat pada proses pembelajaran yang masih sangat berorientasi pada proses menghafal dan mengingat akan teori, konsep, prinsip, postulat, bahkan nilai-nilai pun dihapal. Hal ini terjadi sebagai gejala umum pada setiap mata pelajaran di sekolah yang menyebabkan proses pembelajaran menjadi kurang mampu menanamkan daya nalar peserta didik.

Padahal, sebagaimana dijelaskan Ausuble, bahwa pendidikan hafalan dan drill adalah bentuk pendidikan yang tidak bermakna, atau menurut Paulo Freire (1999), Pendidikan seperti ini adalah pendidikan yang membelenggu dan tidak manusiawi.

\footnotetext{
${ }^{8}$ Moh. Kasiram, Pelaksanaan Pendidikan Agama pada Sekolah- Sekolah di Kota Malang, (Kota: Penerbit, tahun), 78-79.
} 
Maka tidak aneh, bila hasil pendidikan selama ini selalu menghasilkan siswa yang berpikir linear, tidak kreatif. Karena memang sekolah hanya mengembangkan otak kiri ketimbang otak kanan siswa. Bila sudah demikian, kurikulum apapun yang digunakan akan mendapatkan hasil yang sama, yaitu pembodohan. Oleh karena itu sudah saatnya sistem pendidikan yang selama ini ada harus dirubah terlebih-lebih untuk Sekolah Menegah Atas, terutama pada pendidikan Agama Islam. Sehingga siswa tidak lagi merasa jenuh/bosan, akan tetapi menjadi menyenangkan bagi siswa, untuk mengembangkan dan mengembalikan semangat belajar siswa serta menjadikan proses belajar siswa lebih bermakna dan mampu mengaitkan materi dengan kehidupan sehari-hari.

Dari sini diperlukan kreativitas yang harus dilakukan oleh semua pihak baik pihak guru maupun siswa, terutama guru. Karena guru sangat berpengaruh terhadap motivasi belajar siswa dan guru dituntut untuk lebih kreatif dalam merangsang pembelajaran dan mengembangkan kreativitas siswa. Tentunya siswa juga harus dapat belajar kreatif supaya dapat mengembangkan dan menemukan solusi secara mandiri. Karena pendidikan yang kreatif dapat memecahkan segala problem dengan solusi yang cepat dan tepat. Belajar kreatif memungkinkan timbulnya ide-ide baru, caracara baru dan hasil-hasil yang dapat menghasilkan sumbangan bagi pembangunan nasional Indonesia.

Adapun dalam usaha menerapkan pendekatan pembelajaran yang sistematis, kreatif dan menyenangkan. Salah satu Sekolah Menegah Pertama di Surabaya yang lebih dikenal dengan nama VIII SMPN 35 Surabaya telah berupaya menerapkan model pembelajaran baru yang dapat menciptakan suasana belajar yang menyenangkan dan dapat mengembangkan kreativitas belajar siswa. Adapun metode yang digunakan tersebut bernama "Model Pembelajaran Edutainment", yang mana edutainment itu sendiri adalah suatu proses pembelajaran yang didesain sedemikian rupa sehingga muatan pendidikan dan hiburan dapat dikombinasikan secara harmonis yang menjadikan pembelajaran terasa menyenangkan. 


\section{Landasan Teori}

1. Pembelajaran Edutainment

Sebagaimana telah dijelaskan Sutrisno dalam bukunya "Revolusi Pendidikan di Indonesia" bahwa Edutainment berasal dari kata "education" (Pendidikan) dan "entertainment" (Hiburan). Jadi, edutainment dari segi bahasa berarti pendidikan yang menghibur atau menyenangkan. Sedangkan dari segi terminologi, edutainment adalah suatu proses pembelajaran yang didesain sedemikian rupa sehingga muatan pendidikan dan hiburan dapat dikombinasikan secara harmonis. Sehingga pembelajaran terasa lebih menyenangkan. Pembelajaran yang menyenangkan biasanya dilakukan dengan humor, permainan (game), bermain peran (role-play) dan demonstrasi, tetapi dapat juga dengan rasa-rasa senang, dan mereka menikmatinya. ${ }^{9}$ Perpaduan antara belajar dan bermain ini mengacu pada sifat alamiah anak yang dunianya adalah dunia bermain. Bagi anak jarak antara belajar dan bermain begitu tipis. Pilihan model pembelajaran edutainment ini juga berlandaskan hasil riset cara kerja otak. Penemuan-penemuan terbaru ini bahwa anak akan belajar efektif bila dalam keadaan fun dan bebas dari tekanan (revolutional learning) Adapun pelajaran yang diterapkan dikemas dalam suasana bermain dan bereksperimen, sehingga belajar tidak lagi membosankan, tetapi justru merupakan arena bermain yang edukatif dan menyenangkan bagi siswa.

2. Kreativitas Belajar

a. Pengertian Kreativitas Belajar

Ada beberapa definisi yang digunakan dalam membatasi maksud yang terkandung dalam pengertian "kreativitas". Tidak dapat dipungkiri bahwa pengertian ini telah menyebar luas dan telah banyak digunakan melalui individu-individu yang memiliki keahlian yang berbeda, peradaban yang variatif, yang secara otomatis hal ini menyebabkan munculnya sejumlah definisi yang berbeda pula. Kata "kreatif" berasal dari bahasa latin "crate" yang berarti menyebabkan tumbuh: Menghasilkan, menciptakan dan mengeluarkan. Kreativitas dapat didefinisikan sebagai suatu gagasan-gagasan yang baru dan berguna (menurut Halpern, dalam Suharnan). Hasan Galunggung memaknai "kreativitas" sebagai kesanggupan mencipta atau daya cipta.

\footnotetext{
${ }^{9}$ Sutrisno, Revolusi Pendidikan di Indonesia: Membedah Metode dan Teknik Pendidikan Berbasis Kompetensi, (Yogyakarta : Ar-Ruzz, 2005), 31.
} 
Dari arti terminologi tersebut, "kreativitas" berarti potensi diri dalam membuat seseuatu atau mendorong agar sesuatu menjadi ada. ${ }^{10}$

Menurut pendapat Munandar, kreativitas memiliki beberapa pengertian dasar sebagai berikut:

a. Kreativitas merupakan kemampuan untuk membuat kombinasi baru berdasarkan data, informasi, atau unsur-unsur yang ada.

b. Kreativitas adalah kemampuan untuk menemukan banyak kemungkinan jawaban terhadap suatu masalah. Jadi, individu tidak terpadu pada satu jawaban. Disini individu memiliki kebebasan berfikir untuk menyatakan gagasan dan pendapat seluas-luasnya tanpa terikat pada aturan-aturan yang kaku.

c. Secara operasional, kreativitas mengandung pengertian sebagai kemampuan mental yang bersifat lancar (fluency), luwes (flexible), asli (orisinil) dan adanya elaborasi.

d. Kreativitas merupakan proses. ${ }^{11}$ Jadi kreativitas merupakan suatu cara melakukan sesuatu dengan berbeda, unik, lebih baik, baru dan bermanfaat.

Pengembangan kreatifitas mengindikasikan besarnya potensi yang dimiliki seseorang. Dalam dunia pendidikan mungkin sedikit banyak juga telah disinggung dalam paparan di atas, secara garis besar dapat dipahami bahwa tujuan dari pembelajaran ialah membantu murid lebih kreatif dalam memecahkan sebuah persoalan. $^{12}$

Dari uraian di atas, dapat disimpulkan bahwa kreativitas adalah kemampuan seseorang untuk menciptakan atau menemukan sesuatu yang baru. Adapun orang yang melakukan kemampuan tersebut dikatakan orang kreatif.

\section{Metode Penelitian}

Dalam penelitian ini, peneliti menggunakan penelitian kualitatif deskriptif. Sebab penelitian ini menitik beratkan pada proses aplikasi "Pelaksanaan pembelajaran edutainment dalam pengembangan kreativitas mata pelajaran PAI", maka metode penelitian yang sesuai dan tepat adalah menggunakan metode penelitian kualitatif.

Penelitian kualitatif berusaha menampilkan secara holistik (utuh) yang membutuhkan kecermatan dalam pengamatan. Sehingga kita dapat memahami secara menyeluruh

\footnotetext{
${ }^{10}$ A. Khudhori Soleh, Pendidikan Islam Kontemporer, (Yogyakarta: Jendela, 2003), 186.

${ }^{11}$ Agoes Dariyo, Psikologi Perkembangan Dewasa Muda, (Jakarta: Grasindo Widya Sarana Indonesia, 2003), 65

${ }^{12}$ Asrori, Psikologi Pendidikan: Pendekatan Multidisipliner, (Purwokerto: Pena Persada, 2020), 34
} 
hasil penelitian. Di samping itu dalam penelitian kualitatif ini peneliti harus terjun langsung ke lapangan guna memperoleh data yang peneliti butuhkan. Penelitian ini berusaha untuk menggambarkan dan mengklasifikasikan fakta/karakteristik fenomena yang ada secara faktual dan cermat, tidak mengandalkan bukti logika matematis, prinsip angka atau metode statistik. Sehingga dapat digambarkan kondisi dan keadaan yang sebenar-benarnya dengan isyarat atau tindakan sosial.

\section{Hasil dan Analisis Penelitian}

Dalam penerapannya, model pembelajaran edutainment pada bidang studi PAI di SMPN 35 Surabaya mempunyai strategi pembelajaran khusus, yakni pembelajaran yang dikemas dalam bentuk hiburan. Metode pembelajaran yang digunakan juga beragam: Metode ceramah, Metode tanya jawab, Metode resitasi (pemberian tugas), Metode diskusi, Metode demonstrasi, Metode teks dril atau latihan, Metode tadabur alam, Metode cerita, Metode gambar. Kreatifitas menjadi bagian penting yang dijadikan landas pijak dalam penerapan model pembelajaran edutainment. Dalam proses belajarnya, model ini juga menekankan pada keterlibatan siswa sebagai subyek pendidikan, yang didukung dengan adanya hubungan yang diliputi keakraban dan keharmonisan antara guru dan peserta didiknya. Terakhir, tidak ada pemaksaan untuk memilih referensi rujukan yang dipakai dalam proses belajar.

Implementasi Model Pembelajaran Edutainment dalam pengembangan kreativitas belajar siswa pada bidang studi PAI di SMP Negeri 35 Surabaya dilakukan dengan menggunakan metode pembelajaran berbeda-beda dan bervariasi yang digunakan secara bergantian, diciptakannya dalam kondisi kelas yang ceria, menyenangkan dan penuh kegembiraan.

Hasil Implementasi Model Pembelajaran Edutainment dalam pengembangan kreativitas belajar siswa pada bidang studi PAI di SMP Negeri 35 Surabaya sangat mendukung dan membantu mengembangkan kreativitas siswa khususnya pada pembelajaran PAI. Hal ini juga disebabkan karena jika siswa belajar dalam situasi dan kondisi yang menyenangkan (belajar sambil bermain) maka rasa percaya diri siswa akan meningkat dan mereka dapat bebas berekspresi dalam berimajinasi tanpa adanya intervensi dari pihak lain. Selain itu siswa akan mempunyai kemampuan dasar untuk menjadi pembelajar yang mampu mengatur diri, memecahkan masalah dan dapat meningkatkan pengembangan pribadi. Dengan suasana yang gembira, riang dan mengasyikkan akan membuat siswa siap belajar dengan mudah karena dapat 
membantu siswa dalam memahami konsep-konsep dan pengertian secara alamiah, serta dapat mengubah sikap negatif menjadi positif.

\section{Kesimpulan dan Rekomendasi}

1. Kesimpulan

Adapun hasil dari implementasi edutainment di SMP Negeri 35 Surabaya adalah: (1) mendukung dan membantu mengembangkan kreativitas siswa khususnya pada pembelajaran PAI; (2) mampu menjadikan siswa mempunyai kemampuan dasar untuk menjadi pembelajar yang mampu mengatur diri, memecahkan masalah dan dapat meningkatkan pengembangan pribadi; (3) membuat siswa siap belajar dengan mudah karena terbantu oleh adanya konsep-konsep dan pengertian secara alamiah, serta dapat mengubah sikap negatif menjadi positif; dan (4) mempengaruhi siswa agar dapat membiasakan nilai-nilai keagamaan dalam kehidupan sehari-hari.

2. Rekomendasi

Kepada kepala SMP Negeri 35 Surabaya dan seluruh pihak sekolah, untuk selalu mengadakan inonasi baru baik mengenai manajemen, SDM, strategi maupun metode pembelajaran pendidikan guna menghasilkan mutu pendidikan yang berkualitas tinggi. Dari pihak sekolah diharapkan dapat menampung semua aspirasi dari masing-masing guru baik mengenai metode, media maupun sarana prasarana yang diperlukan dalam melangsungkan proses pembelajaran. Untuk setiap guru diharapkan dapat lebih meningkatkan kualitas serta profesionalitas sebagai figur yang ditauladani siswa, dengan menambah wawasan dan pengalaman serta selalu mengadakan perubahan ke arah yang lebih baik lagi. Untuk siswa agar selalu berusaha dan semangat belajar dan jangan jemu untuk mencari ilmu supaya mampu berfikir kreatif dan inovatif menuju kemajuan masa mendatang.

\section{Referensi}

Agoes Dariyo. 2003. Psikologi Perkembangan Dewasa Muda. Jakarta: Grasindo Widya Sarana Indonesia.

Ahmad D. Marimbah. 1974. Pengantar Filsafat Pendidikan Islam. Bandung: AlMaarif.

Asrori. 2020. Psikologi Pendidikan: Pendekatan Multidisipliner. Purwokerto: Pena Persada. 
Hanun Asrohah. 2004. Pendidikan Islam dalam KBK: Studi tentang Pengembangan Pembelajaran PAI Model di MIN Malang, Surabaya: Nizamia.

Khudhori Soleh. 2003. Pendidikan Islam Kontemporer. Yogyakarta: Jendela.

Sunan Ibnu Majjah. Juz 1 Hadits No. 224, Bairut: Dar al-Kitab al-Ilmiah, tt

Sutrisno. 2005. Revolusi Pendidikan di Indonesia: Membedah Metode dan Teknik Pendidikan Berbasis Kompetensi. Yogyakarta : Ar-Ruzz.

Syafrudin Nurdin. 2005. Model Pembelajaran yang Memperhatikan Keberagaman Individu Siswa dalam KBK. Jakarta: Quantum Teaching.

Utami Munandar. 2002. Kreativitas dan Keberbakatan: Strategi Mewujudkan Potensi Kreatif dan Anak Berbakat, Jakarta: PT. Gramedia, Pustaka Utama.

UU Sisdiknas. 2005. Pasal 40 Ayat 2. Sisdiknas, Surabaya; Media Center. 